\title{
GEOLOGIC MAP OF THE SUNNYMEAD 7.5' QUADRANGLE, RIVERSIDE COUNTY, CALIFORNIA
}

\author{
By Douglas M. Morton ${ }^{1}$ and Jonathan C. Matti ${ }^{2}$ \\ Digital preparation by Van M. Diep ${ }^{1}$ and Ursula Edwards-Howells ${ }^{3}$ \\ Prepared in cooperation with \\ CALIFORNIA DIVISION OF MINES AND GEOLOGY \\ and \\ U.S. AIR FORCE
}

Open-File Report OF 01-450

2001

This report is preliminary and has not been reviewed for conformity with U.S. Geological Survey editorial standards or with the North American Stratigraphic Code. Any use of trade, firm, or product names in this publication is for descriptive purposes only and does not imply endorsement by the U.S. Government.

\section{U.S. DEPARTMENT OF INTERIOR \\ U.S. GEOLOGICAL SURVEY}

\author{
${ }^{1}$ U.S. Geological Survey \\ Department of Earth Sciences \\ University of California \\ Riverside CA 92521 \\ ${ }^{2}$ U.S. Geological Survey \\ University of Arizona \\ 520 N. Park Avenue \\ Tucson, AZ 85719 \\ ${ }^{3}$ Department of Earth Sciences \\ University of California \\ Riverside, CA 92521
}




\section{TABLE OF CONTENTS}

Introduction

General

How to obtain paper plots

Database contents

Data package

Plot package

Other files

Software utilities

How to obtain the digital files

Digital databases

Postscript plot files

Portable Document Format (.pdf) files

How to extract the geologic map database from the tar files

Digital database

Postscript plot files

How to convert the ARC/INFO interchange (export) files

Digital geologic map specifications

Digital compilation

Base map

Spatial resolution

Map accuracy standards

Faults and landslides

Database specifics

General

Lines

Polygons

Points

References

INTRODUCTION

General

Open-File Report 01-450 contains a digital geologic map database of the Sunnymead 7.5' quadrangle, Riverside County, California that includes:

1. ARC/INFO (Environmental Systems Research Institute, http:/www.esri.com) version 7.2.1 coverages of the various elements of the geologic map.

2. A Postscript file to plot the geologic map on a topographic base, containing a Correlation of Map Units diagram (CMU), a Description of Map Units (DMU), and an index map.

3. Portable Document Format (.pdf) files of:

a. This Readme; includes in Appendix I, data contained in sun_met.txt

b. The same graphic as plotted in 2 above. Test plots have not produced 1:24,000-scale map sheets. Adobe Acrobat page size setting influences map scale.

The Correlation of Map Units and Description of Map Units is in the editorial format of USGS Miscellaneous Investigations Series (I-series) maps but has not been edited to comply with I-map standards. Within the geologic map data package, map units are identified by standard geologic map criteria such as formation-name, age, and lithology. Where known, grain size is indicated on the map by a subscripted letter or letters following the unit symbols as follows: lg, large boulders; b, boulder; g, gravel; a, arenaceous; s, silt; c, clay; e.g. Qyf ${ }_{\mathrm{a}}$ is a predominantly young alluvial fan deposit that is arenaceous. 
Multiple letters are used for more specific identification or for mixed units, e.g., Qfy $\mathrm{s}_{\mathrm{sa}}$ is a silty sand. In some cases, mixed units are indicated by a compound symbol; e.g., Qyf ${ }_{2 s c}$. Marine deposits are in part overlain by local, mostly alluvial fan, deposits and are labeled Qomf. Grain size follows f.

Even though this is an Open-File Report and includes the standard USGS Open-File disclaimer, the report closely adheres to the stratigraphic nomenclature of the U.S. Geological Survey. Descriptions of units can be obtained by viewing or plotting the .pdf file ( $3 \mathrm{~b}$ above) or plotting the postscript file ( 2 above).

This Readme file describes the digital data, such as types and general contents of files making up the database, and includes information on how to extract and plot the map and accompanying graphic file. Metadata information can be accessed at http://geo-nsdi.er.usgs.gov/metadata/open-file/01-450 and is included in Appendix I of this Readme.

\section{HOW TO OBTAIN PAPER PLOTS}

For those having access to large-format plotters such as HP650C, HP755C, and HP2500C, plots may be made directly from the included plot file.

\section{DATABASE CONTENTS}

The files constituting the geologic map database of this Open-File Report are listed below along with the interchange files from which they were extracted.

Data Package

All files listed below are in a compressed tar file named stp.tar.gz (2.7 Mb); see section below titled, SOFTWARE UTILITES.

\begin{tabular}{|c|c|c|}
\hline $\begin{array}{l}\text { ARC/INFO } \\
\text { interchange files }\end{array}$ & $\begin{array}{l}\text { Sunnymead } \\
\text { coverages }\end{array}$ & Contains \\
\hline sun_geo.e00 & sun_geo & Contacts, faults, geologic unit labels \\
\hline sun_ano.e00 & sun_ano & $\begin{array}{l}\text { Annotation subclasses: } \\
\qquad \text { GEO (for plotting unit labels) }\end{array}$ \\
\hline sun_str.e00 & sun_str & $\begin{array}{l}\text { Attitudes and their dip values. Dip } \\
\text { values plotted as annotation. }\end{array}$ \\
\hline
\end{tabular}

The directory, info/, is produced in the process of importing interchange files to ARC coverages in ARC/INFO. The sun (Sunnymead) info/ directory contains:

$\underline{\text { Feature Attribute Tables }}$

Polygon attribute table Arc attribute table

Point attribute table

$$
\begin{aligned}
& \text { sun_geo.pat } \\
& \text { sun_geo.aat } \\
& \text { sun_ano.aat } \\
& \text { sun_str.pat }
\end{aligned}
$$




$\begin{array}{lll}\underline{\text { Raster }} & \text { Resultant image } & \text { Contains } \\ \begin{array}{ll}\text { file } \\ \text { sun.tif }\end{array} & \text { Sunnymead base map } & \text { Topographic base from 500 dpi scan of } \\ & & \text { USGS Sunnymead 7.5' quadrangle, } 1967\end{array}$

Plot Package

Postscript plot files of the geologic map and explanation; please see section below titled, SOFTWARE UTILITIES for additional information.

$\begin{array}{lll}\text { Compressed file } & \text { Resultant image } & \text { Contains } \\ \text { sun_map.ps.gz } & \text { sun_map.ps } & \begin{array}{l}\text { PostScript plot file of geologic map and } \\ \text { CMU/DMU }\end{array}\end{array}$

The Postscript file is compressed using winzip.

The uncompressed PostScript file sun_map.ps will plot a 1:24,000 scale, full color geologic map of the Sunnymead quadrangle on the topographic base. A detailed CMU diagram, a DMU are included on the sheet. The sheet is in the editorial format of the U.S. Geological Survey's Miscellaneous Investigations (I) map series, and is approximately 50 X 36 inches in size. The map sheet has been successfully plotted on Hewlett-Packard large-format plotters, models HP650C, HP755C, and HP2500C.

\section{Symbols Package}

Files in the plot package have been prepared to produce optimum plots using the shade and marker sets and fonts listed below; these symbol sets and fonts are included in a compressed tar file named symbols.tar.gz $(0.04 \mathrm{Mb})$; see section below titled SOFTWARE UTILITIES.

$\begin{array}{ll}\text { geoSCAMP2.lin } & \text { Lineset } \\ \text { geoSCAMP2.mrk } & \text { Markerset for points } \\ \text { alc1.shd } & \text { Colors } \\ \text { geology2.shd } & \text { Pattern fills } \\ \text { fnt026 } & \text { Font required for geoSCAMP2.lin } \\ \text { fnt037 } & \text { Font required for geoSCAMP2.mrk } \\ \text { fnt035 } & \text { Font required for geology2.shd }\end{array}$

Special geologic characters used in unit designations are from the Geoage font group and may be obtained at the following web site:
Server:
onyx.wr.usgs.gov
UserID:
anonymous
Password:
Your e-mail address
Directory:
pub/wpg/supplies/geoage

0 ther files

\author{
README.pdf \\ sun_map.pdf
}

This document

Postscript plot file of geologic map and CMU/DMU

SOFTW ARE UTILITIES 
Files which have a .gz file extension were compressed using gzip. Gzip utilities are available free of charge via the Internet at the gzip home page, http://www.gzip.org. Files with a .zip file extension were compressed using WinZip, available at http://www.winzip.com.

The data package and symbols package are additionally bundled into a single tar (tape archive) file. The individual files must be extracted using a tar utility, available free of charge via the Internet through links on the Common Internet File Formats page, http://www.matisse.net/files/format.html. One such utility is WinZip, available at http://www.winzip.com.

\section{HOW TO OBTAIN THE DIGITAL FILES}

The export files, and subsequently the data and plot files, constituting the geologic map database of this Open-File Map may be obtained in two ways, both over the Internet.

1. The files can be obtained via the Web from Western Region Geologic Information Server. Go to the web page at http://geopubs.wr.usgs.gov/open-file/of01-450 and follow the directions to download the files.

2. The files can also be obtained by anonymous ftp over the Internet from wrgis.wr.usgs.gov. The files are located in the directory/pub/open-file/. Be sure to use binary transfer mode or ASCII mode for individual .e00 (ARC interchange file format) files.

\section{HOW TO EXTRACT THE GEOLOGIC MAP DATABASE FROM THE TAR FILE}

\section{Digital database}

After downloading the files, they must be uncompressed using a gzip utility such as gzip itself or WinZip. The data files must then be extracted using a tar utility or Winzip.

This process will create a directory, sun/, that will contain the ARC/INFO interchange files and supporting files. The directory should contain the following files:

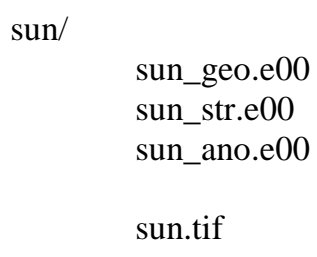

The symbols.tar.gz file is imported using the same methods as for the $1 \mathrm{~km} . t a r . g z$ file. It will create a directory, symbols/ that will contain the following files:

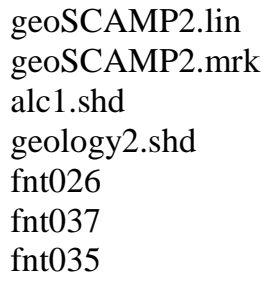

The following are not included in the database tar file, and are downloaded separately.

$$
\begin{aligned}
& \text { sun_map.ps.gz } \\
& \text { Readme.pdf } \\
& \text { sun_map.pdf }
\end{aligned}
$$




\section{Postscript plot files}

Make a 15 MB uncompressed file, sun_map.ps (plot of complete map), by typing gzip -d sun_map.ps.gz (or use gzip utility of choice).

\section{Portable Document Format (.pdf) files}

PDF files are not stored as gzip files. They are accessed using Adobe Acrobat Reader software, available free from the Adobe website http://www.adobe.com. Follow instructions at the website to download and install the software. Acrobat Reader contains an on-line manual and tutorial.

\section{HOW TO CONVERT THE ARC/INFO INTERCHANGE (EXPORT) FILES}

The ARC interchange (.e00) files are converted to ARC coverages using the ARC command IMPORT.

ARC interchange files can also be read by some other Geographic Information Systems, including ArcView (ESRI) and MapInfo (http://www.mapinfo.com), (Environmental Systems Research Institute, Inc., 1998). Please consult your GIS documentation to see if you can use ARC interchange files and the procedure to import them.

\section{DIGITAL GEOLOGIC MAP SPECIFICATIONS}

Digital compilation

The geologic map information was hand digitized from a base-stable original (ink on a greenline) of the geologic map at 1:24,000 scale. Digital tics were placed by hand at latitude/longitude intersections. The lines, points, and polygons were edited using standard ARC/INFO commands, and in some places, interactively by hand using graphical user interface ALACARTE (Fitzgibbon, 1991, Fitzgibbon and Wentworth, 1991, Wentworth and Fitzgibbon, 1991). Digitization and editing artifacts significant enough to display at a scale of 1:24,000 were corrected.

\section{Base map}

The base map image (sun.tif) was prepared by scanning a scale-stable clear film of the U.S. Geological Survey, 1:24,000 Sunnymead 7.5' quadrangle (1967) topographic map. Scanning was done using an Anatech Eagle 4080 monochrome 800 dpi scanner; at a resolution of 500 dpi. The raster scan was converted to a monochromatic image in ARC/INFO, and registered and rectified to the Sunnymead 7.5' quadrangle. No elements of the base layer are attributed. The base map is provided for reference only.

\section{Spatial resolution}

Use of this digital geologic map database should not violate the spatial resolution of the data. Although the digital form of the data removes the constraint imposed by the scale of a paper map, the detail and accuracy inherent in map scale are also present in the digital data. The fact that this database was edited at a scale of 1:24,000 means that higher resolution information is not generally present in the dataset. Plotting at scales larger than 1:24,000 will not yield greater real detail, although it may reveal fine-scale irregularities above the intended resolution of the database. Similarly, although higher resolution data is incorporated at a few places, the resolution of the combined output will be limited by the lower resolution data. 
Until uniform National geologic map standards are developed and adopted, lines and points on SCAMP 1:24,000 scale geologic maps that are located to within 15 meters, relative to accurately located features on the base map, are considered to meet map accuracy standards. Dashed lines, indicated in the database as approximately located or inferred, are generally located within 30 meters, relative to accurately located features on the base map.

\section{F aults and landslides}

This database is sufficiently detailed to identify and characterize many actual and potential geologic hazards represented by faults and landslides, but it is not sufficiently detailed for site-specific determinations. Faults shown do not take the place of fault rupture hazard zones designated by the California State Geologist (see Hart, 1998).

Database specifics

General--The map database consists of ARC/INFO format coverages, which are stored in polyconic projection (Table 1), and a series of data tables. Digital tics define a 2.5 minute grid of latitude and longitude in the geologic coverages corresponding to the 2.5 minute tic grid on the topographic base map.

$\begin{array}{ll}\text { Table 1 --- } & \text { Map Projection } \\ \text { Projection } & \text { Polyconic } \\ \text { Datum } & \text { NAD27 } \\ \text { Zunits } & \text { No } \\ \text { Units } & \text { Meters } \\ \text { Spheroid } & \text { Clark 1866 } \\ \text { X shift } & 0.000000000 \\ \text { Y shift } & 0.000000000 \\ \text { Parameters } & -1171115.000 \text { longitude of central meridian } \\ & 335230.00 \text { latitude of projections origin } \\ & 0.00000 \text { false easting (meters) } \\ & 0.00000 \text { false northing (meters) }\end{array}$

The content of the geologic database can be described in terms of feature classes that include lines, points, and areas that compose the map. See the metadata text file (Appendix I) for detailed descriptions.

Lines - Lines are recorded as strings of arcs and are described in an arc attribute (.aat) table. Complete lists of the line types (LTYPE) used in the quadrangle are available in Appendix I. They represent contacts and faults, which define the boundaries of map units and map boundaries.

Polygons --- Geologic map units (polygons) are described in the polygon attribute (.pat) table (details in Appendix I). For traditional descriptions of the map units, see the Portable Document Format file sun_map.pdf or the Postscript map plot, sun_map.ps. A list of all map units in the database is given in Appendix I.

Points - Point information (attitudes of planar and linear features) is recorded as coordinate and related information. Complete lists of the point types (PTTYPE) used in the point coverage are available in Appendix I. 


\section{REFERENCES}

Environmental Systems Research Institute, Inc, 1991, ARC/INFO command references 6.0: Proprietary software manual

Fitzgibbon, T.T., 1991, ALACARTE installation and system manual (version 1.0): U.S. Geological Survey, Open-File Report 91-587B

Fitzgibbon, T.T., and Wentworth, C.M., 1991, ALACARTE user interface - AML code and demonstration Maps (version 1.0): U.S. Geological Survey, Open-File Report 91-587A

Wentworth, C.M., and Fitzgibbon, T.T., 1991, ALACARTE user manual (version 1.0): U.S. Geological Survey Open-File Report 91-587C

\section{Appendix I}

(Original metadata text)

Identification_Information:

Citation:

Citation_Information:

Originator: Douglas M. Morton

Originator: Jonathan C. Matti

Publication_Date: 2001

Title: Geologic Map of the Sunnymead 7.5' Quadrangle, Riverside County, California

Edition: (Version 1.0, October 03, 2001)

Geospatial_Data_Presentation_Form: vector digital data

Series_Information:

Series_Name: U.S. Geological Survey Open-File Report

Issue_Identification: USGS OFR 01-450

Publication_Information:

Publication_Place: Menlo Park, California

Publisher: U.S. Geological Survey

Online_Linkage: http://geopubs.wr.usgs.gov/open-file/of01-450

Description:

Abstract:

This data set maps and describes the geology of the Sunnymead 7.5' quadrangle, Riverside County, California. Created using Environmental Systems Research Institute's ARC/INFO software, the data base consists of the following items: (1) a map coverage containing geologic contacts and units, (2) a coverage containing structural data, (3) a coverage containing geologic unit annotation and leaders, and (4) attribute tables for geologic units (polygons), contacts (arcs), and site-specific data (points). In addition, the data set includes the following graphic and text products: (1) a postscript graphic plot-file containing the geologic map, topography, cultural data, a Correlation of Map Units (CMU) diagram, a Description of Map Units (DMU), and a key for point and line symbols, and (2) PDF files of the Readme (including the metadata file as an appendix), and the graphic produced by the Postscript plot file.

The Sunnymead quadrangle is located in the northern part of the Peninsular Ranges Province and is underlain by Cretaceous and older basement rocks. This part of the Peninsular Ranges Province is divided into the Perris block, located west of the San Jacinto fault and the San Jacinto Mountains block to the east. The northwest quarter of the quadrangle is crossed diagonally by the San Jacinto fault zone, an important active major fault of the San Andreas fault system. The San Jacinto fault zone consist of a main trace and multiple discontinuous breaks. The main trace forms a dissected, west-facing fault scarp about 1,000 feet 
above the valley floor. A vaguely located fault in granitic rocks parallel to and west of the San Jacinto fault zone does not appear to cut Pleistocene age alluvial deposits.

On the northern side of the San Jacinto fault zone is a thick section of Pliocene and Pleistocene continental sedimentary rocks, the upper part of the San Timoteo beds of Frick(1921). The area underlain by these rocks is termed the San Timoteo Badlands. Most of these beds consist of coarse-grained sandstone, conglomeratic sandstone, and conglomerate. All the clasts within these beds were derived from Transverse Ranges basement rocks that are located to the north of the quadrangle. The San Timoteo beds have been deformed into a broad anticlinal structure produced by the sedimentary beds being compressed as they are translated around a restraining bend in the San Jacinto fault north of the El Casco quadrangle. A curving, diachronous fault produced by this compression is located in the western part of the badlands just east of the San Jacinto fault zone.

The area west of the San Jacinto fault zone is underlain by plutonic rocks of the Cretaceous-age Peninsular Ranges batholith with a few small included pendants of schist and gneiss of probable Paleozoic age. Most of the plutonic rocks are of tonalite composition and are mainly biotite-hornblende tonalite. In the northwestern part of the quadrangle is the eastern part of the Box Springs granitic complex, a basinalshaped complex that appears to be the distal part of a diapiric-shaped complex.

Most of the alluviated area west of the San Jacinto fault zone consists of Pleistocene age fluvial deposits. Most of these deposits have a degraded upper surface. The upper surface of these deposits are preserved in some places near the contact with granitic rocks. The upper part of these deposits form the Paloma surface of Woodford and others(1971). Holocene age alluvial fans emanate from the San Timoteo Badlands.

The geologic map data base contains original U.S. Geological Survey data generated by detailed field observation recorded on 1:24,000 scale aerial photographs. The map was created by transferring lines from the aerial photographs to a 1:24,000 scale topographic base. The map was digitized and lines, points, and polygons were subsequently edited using standard ARC/INFO commands. Digitizing and editing artifacts significant enough to display at a scale of 1:24,000 were corrected. Within the database, geologic contacts are represented as lines (arcs), geologic units are polygons, and site-specific data as points. Polygon, arc, and point attribute tables (.pat, .aat, and .pat, respectively) uniquely identify each geologic datum.

Purpose: The data set for the Sunnymead 7.5' quadrangle was prepared under the U.S. Geological Survey Southern California Areal Mapping Project (SCAMP) as part of an ongoing effort to develop a regional geologic framework of southern California, and to utilize a Geographic Information System (GIS) format to create regional digital geologic databases. These regional databases are being developed as contributions to the National Geologic Map Database of the National Cooperative Geologic Mapping Program of the USGS.

Supplemental_Information: none

Time_Period_of_Content:

Time_Period_Information:

Single_Date/Time:

Calendar_Date: 2001

Currentness_Reference: New data

Status:

Progress: Complete

Maintenance_and_Update_Frequency: As Needed

Spatial_Domain:

Bounding_Coordinates:

West_Bounding_Coordinate: -117.25009155

East_Bounding_Coordinate: -117.12490863

North_Bounding_Coordinate: 34.00000057

South_Bounding_Coordinate: 33.87498338

Keywords:

Theme:

Theme_Keyword_Thesaurus: None

Theme_Keyword: geologic map 
Theme_Keyword: geology

Theme_Keyword: bedrock geology

Theme_Keyword: alluvial geology

Theme_Keyword: fault

Place:

Place_Keyword_Thesaurus: None

Place_Keyword: California

Place_Keyword: Riverside County

Place_Keyword: Sunnymead 7.5' quadrangle

Stratum:

Stratum_Keyword_Thesaurus: None

Stratum_Keyword: Cretaceous tonalite and granodiorite

Stratum_Keyword: Quaternary deposits

Stratum_Keyword: San Jacinto Fault

Temporal:

Temporal_Keyword_Thesaurus: None

Temporal_Keyword: Cretaceous

Temporal_Keyword: Quaternary

Access_Constraints: None

Use_Constraints:

The Sunnymead 7.5' geologic-map database should be used to evaluate and understand the geologic character of the Sunnymead 7.5' quadrangle as a whole. The data should not be used for purposes of sitespecific land-use planning or site-specific geologic evaluations. The database is sufficiently detailed to identify and characterize many actual and potential geologic hazards represented by faults and landslides and posed by ground subsidence and earthquake-generated ground shaking. However, it is not sufficiently detailed for site-specific determinations or evaluations of these features. Faults shown do not take the place of fault-rupture hazard zones designated by the California State Geologist (see Hart, 1988).

Use of this digital geologic-map database should not violate the spatial resolution of the data. Although the digital form of the data removes the constraint imposed by the scale of a paper map, the detail and accuracy inherent in map scale are also present in the digital data. The fact that this database was compiled and edited at a scale of 1:24,000 means that higher resolution information may not have been uniformly retained in the dataset. Plotting at scales larger than 1:24,000 will not yield greater real detail, although it may reveal fine-scale irregularities below the intended resolution of the database. Similarly, although higher resolution data is incorporated in most of the map, the resolution of the combined output will be limited by the lower resolution data.

Point_of_Contact:

Contact_Information:

Contact_Person_Primary:

Contact_Person: Douglas M. Morton

Contact_Organization: U.S. Geological Survey, Western Region, Earth Surface Processes Team

Contact_Position: Project geologist

Contact_Address:

Address_Type: mailing address

Address: U.S. Geological Survey

Address: Department of Earth Sciences

Address: University of California, Riverside

City: Riverside

State_or_Province: California

Postal_Code: 92521

Country: United States of America

Contact_Voice_Telephone: (909) 276-6397

Contact_Facsimile_Telephone: (909) 276-6295

Contact_Electronic_Mail_Address: scamp@usgs.gov 
Data_Set_Credit: Geologic mapping and digital preparation of this report were sponsored jointly by (1) the National Cooperative Geologic Mapping Program of the U.S. Geological Survey, (2) the California Division of Mines and Geology, (3) the Southern California Areal Mapping Project (SCAMP), and (4) the U.S. Air Force.

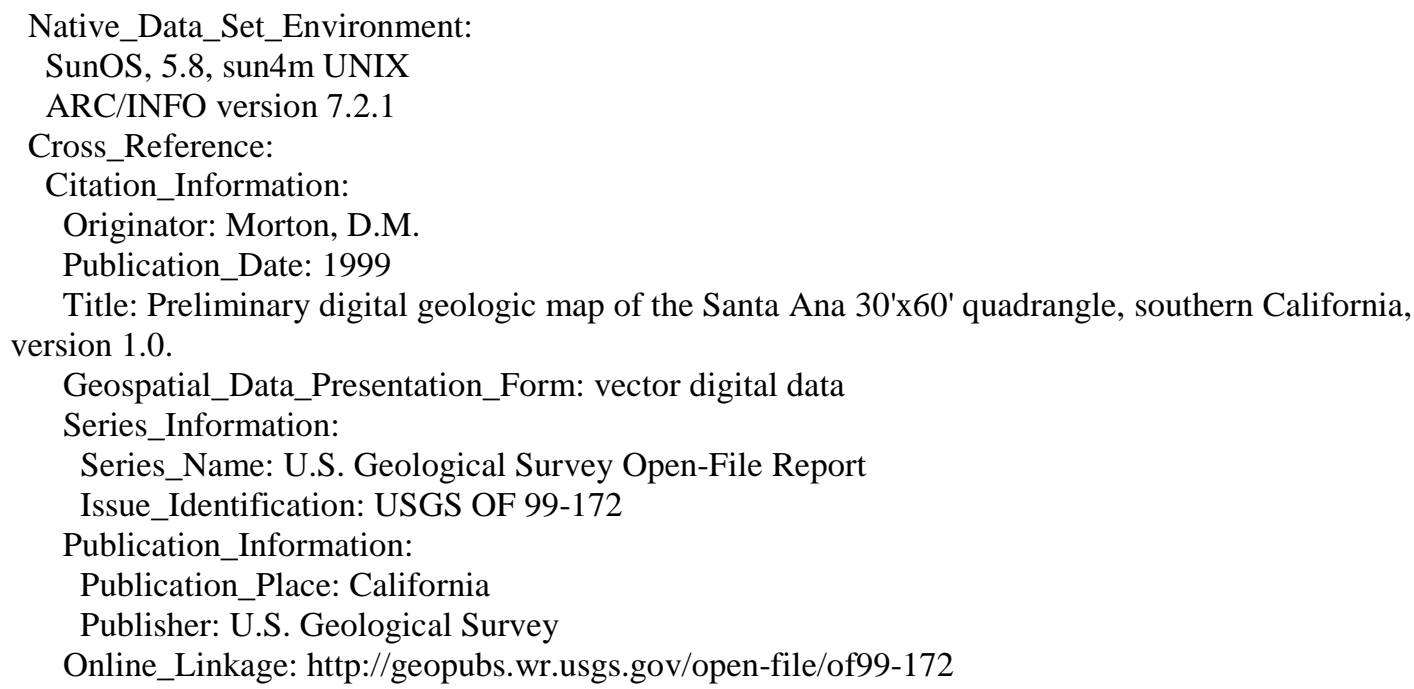

Title: Preliminary digital geologic map of the Santa Ana 30'x60' quadrangle, southern California, version 1.0 .

Geospatial_Data_Presentation_Form: vector digital data

Series_Information:

Series_Name: U.S. Geological Survey Open-File Report

Issue_Identification: USGS OF 99-172

Publication_Information:

Publication_Place: California

Publisher: U.S. Geological Survey

Online_Linkage: http://geopubs.wr.usgs.gov/open-file/of99-172

Data_Quality_Information:

Attribute_Accuracy:

Attribute_Accuracy_Report:

Geologic-map units in the Sunnymead quadrangle database were described using standard field methods. Consistent with these methods, the database author has assigned standard geologic attributes to geologic lines, points, and polygons identified in the database.

Nation-wide geologic-map accuracy standards have not been developed and adopted by the U.S. Geological Survey and other earth-science entities. Until such standards are adopted, the SCAMP project has developed internal map-accuracy standards for 1:24,000-scale geologic maps produced by the project. Geologic lines and points on 1:24,000 scale geologic maps are judged to meet SCAMP's internal mapaccuracy standards if they are located to within $+/-15$ meters, relative to topographic or cultural features on the base map. On any derivative geologic-map plot, line data that are judged to meet the SCAMP internal map-accuracy standard are denoted by solid lines; line data that may not meet the SCAMP internal mapaccuracy standard are denoted by dashed or dotted lines. There is no cartographic device for denoting the map-accuracy for geologic-point data (e.g., symbols representing bedding, foliation, lineations, etc.).

Logical_Consistency_Report:

Polygon and chain-node topology present.

The areal extent of the map is represented digitally by an appropriately projected (polyconic projection), mathematically generated box. Consequently, polygons intersecting the lines that comprise the map boundary are closed by that boundary. Polygons internal to the map boundary are completely enclosed by line segments which are themselves a set of sequentially numbered coordinate pairs. Point data are represented by coordinate pairs.

Completeness_Report: The geologic map database of the Sunnymead 7.5' quadrangle contains new data that have been subjected to rigorous review and are a substantially complete representation of the current state of knowledge concerning the geology of the quadrangle.

Positional_Accuracy:

Horizontal_Positional_Accuracy:

Horizontal_Positional_Accuracy_Report: The maximum transformation RMS error acceptable for a 7.5' quadrangle transformation and data input is 0.003 (1.8 meters). Horizontal positional accuracy was checked by visual comparison of hard-copy plots with base-stable source data.

Lineage:

Process_Step: 
Process_Description: Field mapping and aerial photograph interpretation; iterative process (D.M. Morton).

Process_Date: 1978, 1996-97

Process_Step:

Process_Description: Field mapping and aerial photograph interpretation; iterative process (J.C. Matti).

Process_Date: 1988, 1997

Process_Step:

Process_Description: Digitization of geologic linework and point data from a scale-stable cartographic base of quadrangle. ARC/INFO database established; cleanup of artifacts; polygon, arc, and point attribute tables established. Digitizing and editing artifacts significant enough to display at a scale of 1:24,000 were corrected (V.M. Diep and U. Edwards-Howells).

Process_Date: 1999-2001

Process_Step:

Process_Description: Description of map units and correlation of map units (F.K. Miller).

Process_Date: 2001

Process_Step:

Process_Description:

First draft of metadata created by Michael J. Watson using FGDCMETA.AML ver. 1.2 05/14/98 on ARC/INFO data set

/scamp26/mwatson/sun_ofr/sun_geo

Process_Date: 20011003

Spatial_Data_Organization_Information:

Direct_Spatial_Reference_Method: Vector

Point_and_Vector_Object_Information:

SDTS_Terms_Description:

SDTS_Point_and_Vector_Object_Type: Point

Point_and_Vector_Object_Count: 440

SDTS_Point_and_Vector_Object_Type: String

Point_and_Vector_Object_Count: 1261

SDTS_Point_and_Vector_Object_Type: GT-polygon composed of chains

Point_and_Vector_Object_Count: 441

Spatial_Reference_Information:

Horizontal_Coordinate_System_Definition:

Planar:

Map_Projection:

Map_Projection_Name: Polyconic

Polyconic:

Latitude of True Scale: $\quad 33.875$

Longitude_of_Central_Meridian: -117.1875

False_Easting: 0.00000

False_Northing: 0.00000

Planar_Coordinate_Information:

Planar_Coordinate_Encoding_Method: coordinate pair

Coordinate_Representation:

Abscissa_Resolution: 1.000396490097

Ordinate_Resolution: 1.000396490097

Planar_Distance_Units: Meters

Geodetic_Model:

Horizontal_Datum_Name: North American Datum of 1927

Ellipsoid_Name: Clarke 1866

Semi-major_Axis: 6378206.4

Denominator_of_Flattening_Ratio: 294.98

Entity_and_Attribute_Information: 
Overview_Description:

Entity_and_Attribute_Overview:

Version 1.0 of the Sunnymead 7.5' quadrangle comprises three ARC/INFO coverages, of which two contain geologic data, and one contains cartographic features: sun_geo (geology), sun_str (structural data), and sun_ano (annotation and leaders).

Geologic data represented by line entities and the polygons they delineate are contained in the coverage SUN_GEO. For display purposes, the annotation coverage contains one annotation subclass: anno.geo contains unit labels.

Geological point data includes site-specific information describing the types and the orientation of bedding, foliation, and lineations. Annotation is respective dip and plunge values associated with individual point data.

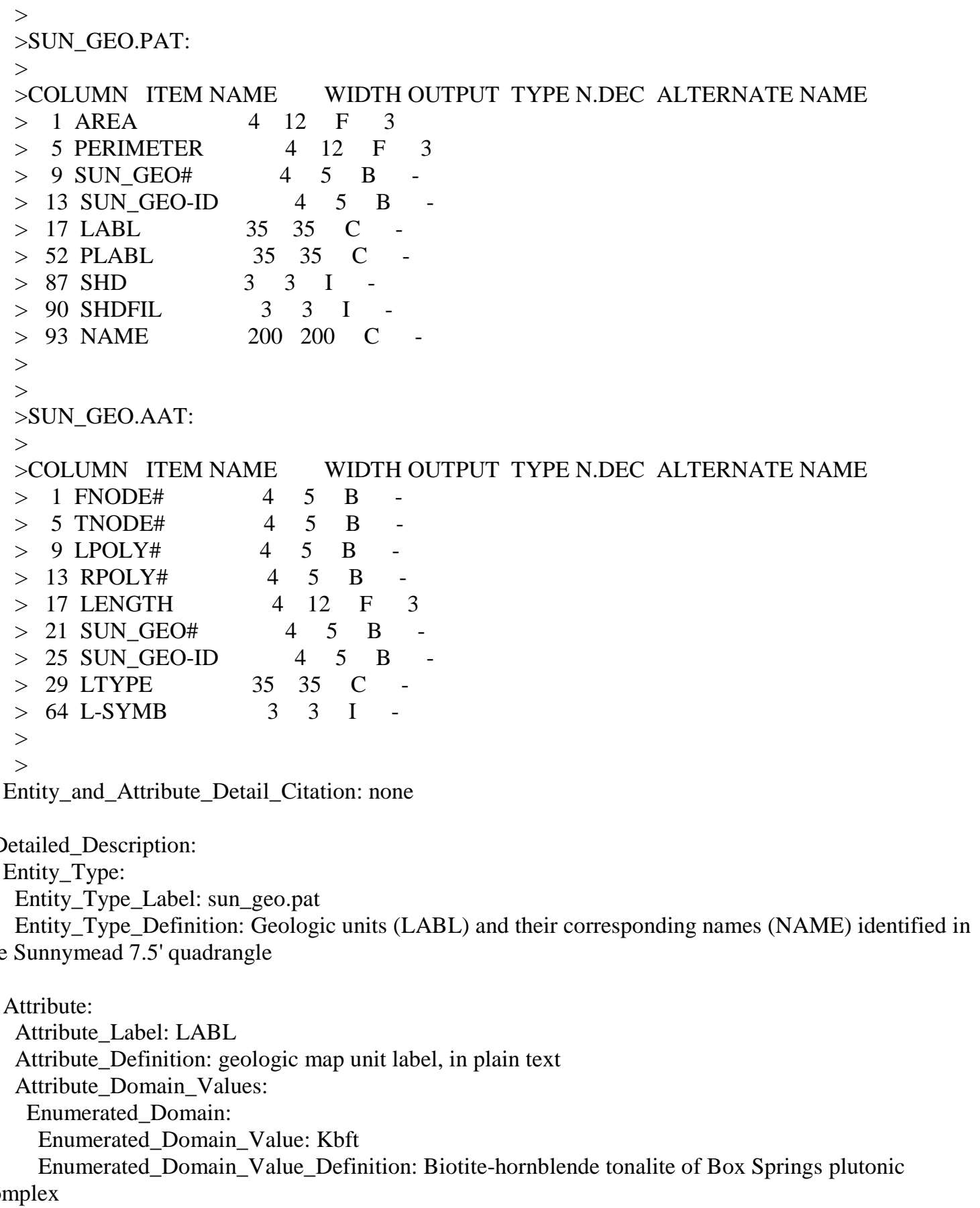


Enumerated_Domain:

Enumerated_Domain_Value: Kbg

Enumerated_Domain_Value_Definition: Porphyritic granodiorite of Box Springs plutonic complex

Enumerated_Domain:

Enumerated_Domain_Value: Kbhg

Enumerated_Domain_Value_Definition: Heterogeneous porphyritic granodiorite of Box Springs

plutonic complex

Enumerated_Domain:

Enumerated_Domain_Value: Kg

Enumerated_Domain_Value_Definition: Granitic dikes

Enumerated_Domain:

Enumerated_Domain_Value: Kgu

Enumerated_Domain_Value_Definition: Granite, undifferentiated

Enumerated_Domain:

Enumerated_Domain_Value: Khg

Enumerated_Domain_Value_Definition: Heterogeneous granitic rocks

Enumerated_Domain:

Enumerated_Domain_Value: Kqd

Enumerated_Domain_Value_Definition: Quartz diorite, undifferentiated

Enumerated_Domain:

Enumerated Domain Value: Kt

Enumerated_Domain_Value_Definition: Tonalite, undifferentiated

Enumerated_Domain:

Enumerated_Domain_Value: Ktm

Enumerated_Domain_Value_Definition: Tonalite and mafic rocks, undifferentiated

Enumerated_Domain:

Enumerated_Domain_Value: Pzs

Enumerated_Domain_Value_Definition: Biotite schist

Enumerated_Domain:

Enumerated_Domain_Value: QTstc

Enumerated_Domain_Value_Definition: Quartzite-bearing conglomerate beds of San Timoteo beds of Frick (1921)

Enumerated_Domain:

Enumerated_Domain_Value: QTsts

Enumerated_Domain_Value_Definition: Conglomeratic sandstone beds of San Timoteo beds of Frick (1921)

Enumerated_Domain:

Enumerated_Domain_Value: QTstu

Enumerated_Domain_Value_Definition: Upper member of San Timoteo beds of Frick (1921)

Enumerated_Domain:

Enumerated_Domain_Value: Qa

Enumerated_Domain_Value_Definition: Axial channel deposits

Enumerated_Domain:

Enumerated_Domain_Value: Qaf

Enumerated_Domain_Value_Definition: Artificial fill

Enumerated Domain:

Enumerated_Domain_Value: Qfag

Enumerated_Domain_Value_Definition: Alluvial fan deposits, arenaceous gravel

Enumerated_Domain:

Enumerated_Domain_Value: Q1s

Enumerated_Domain_Value_Definition: Landslide deposits

Enumerated_Domain:

Enumerated_Domain_Value: Qofa

Enumerated_Domain_Value_Definition: Old alluvial fan deposits, arenaceous

Enumerated_Domain:

Enumerated_Domain_Value: Qofag 
Enumerated_Domain_Value_Definition: Old alluvial fan deposits, arenaceous gravel

Enumerated_Domain:

Enumerated_Domain_Value: Qols

Enumerated_Domain_Value_Definition: Old landslide deposits

Enumerated_Domain:

Enumerated_Domain_Value: Qvofla

Enumerated_Domain_Value_Definition: Very old alluvial fan deposits, unit 1, arenaceous

Enumerated_Domain:

Enumerated_Domain_Value: Qvofa

Enumerated_Domain_Value_Definition: Very old alluvial fan deposits, arenaceous

Enumerated_Domain:

Enumerated_Domain_Value: Qvols

Enumerated_Domain_Value_Definition: Very old landslide deposits

Enumerated_Domain:

Enumerated_Domain_Value: Qwag

Enumerated_Domain_Value_Definition: Wash deposits, arenaceous gravel

Enumerated_Domain:

Enumerated_Domain_Value: Qyaa

Enumerated_Domain_Value_Definition: Young axial channel deposits, arenaceous

Enumerated_Domain:

Enumerated_Domain_Value: Qyaag

Enumerated_Domain_Value_Definition: Young axial channel deposits, arenaceous gravel

Enumerated_Domain:

Enumerated_Domain_Value: Qyfa

Enumerated_Domain_Value_Definition: Young alluvial fan deposits, arenaceous

Enumerated_Domain:

Enumerated_Domain_Value: Qyfag

Enumerated_Domain_Value_Definition: Young alluvial fan deposits, arenaceous gravel

Enumerated_Domain:

Enumerated_Domain_Value: Qyls

Enumerated_Domain_Value_Definition: Young landslide deposits

Enumerated_Domain:

Enumerated_Domain_Value: Qyva

Enumerated_Domain_Value_Definition: Young alluvial valley deposits, arenaceous

Enumerated_Domain:

Enumerated_Domain_Value: Qyvsa

Enumerated_Domain_Value_Definition: Young alluvial valley deposits, silt arenaceous

Enumerated_Domain:

Enumerated_Domain_Value: Qywa

Enumerated_Domain_Value_Definition: Young wash deposits, arenaceous

Enumerated_Domain:

Enumerated_Domain_Value: Qywag

Enumerated_Domain_Value_Definition: Young wash deposits, arenaceous gravel

Enumerated_Domain:

Enumerated_Domain_Value: Tstd

Enumerated_Domain_Value_Definition: Middle member conglomerate of San Timoteo beds of Frick (1921)

Enumerated_Domain:

Enumerated_Domain_Value: Tstm

Enumerated_Domain_Value_Definition: Middle member of San Timoteo beds of Frick (1921) Attribute:

Attribute_Label: PLABL

Attribute_Definition: Geological map unit label used to generate plot labels with relevant stratigraphic symbols. The geologic units with LABL designating Mesozoic (Mz) have keystroke substitute characters, \}, that call their corresponding symbols from the Stratagem Font Group. Geologic map unit labels will plot 
on derivative map plots with appropriate stratigraphic symbols if PLABL is used as the source for unit labels.

Attribute:

Attribute_Label: SHD

Attribute_Definition: polygon color (as integer value) from shadeset alc1.shd (included in the symbols package)

Attribute:

Attribute_Label: SHDFIL

Attribute_Definition: polygon fill pattern (as integer value) from shadeset geology2.shd (included in the symbols package)

Attribute:

Attribute_Label: NAME

Attribute_Definition: Geologic name of map unit (see list under LABL attribute)

Detailed_Description:

Entity_Type:

Entity_Type_Label: sun_geo.aat

Entity_Type_Definition: Geologic features such as contacts and faults that bound rock-unit polygons

Attribute:

Attribute_Label: LTYPE

Attribute_Definition: Description of types of lines on the geologic map (contact, fault).

Attribute_Domain_Values:

Enumerated_Domain:

Enumerated_Domain_Value: contact, certain

Enumerated_Domain_Value: fault, certain

Enumerated_Domain_Value: fault, approx. located

Enumerated_Domain_Value: fault, concealed

Enumerated_Domain_Value: fault, queried

Enumerated_Domain_Value: fault, approx. located, queried

Enumerated_Domain_Value: Kg, granitic dike

Enumerated_Domain_Value: map boundary

Attribute:

Attribute_Label: L-SYMB

Attribute_Definition: stores appropriate line symbol value from the lineset geoscamp2.lin

Detailed_Description:

Entity_Type:

Entity_Type_Label: sun_str.pat

Entity_Type_Definition: Geological point data includes site-specific information describing the types and the orientation of bedding, foliation, and lineations. One annotation subclass is included in the geologic points coverage, SUN_STR which displays the respective dip and plunge values associated with individual point data.

Attribute:

Attribute_Label: PTTYPE

Attribute_Definition: describes type of point data (bedding, horizontal bedding, foliation)

Attribute:

Attribute_Label: P-SYMB

Attribute_Definition: Coded integer value that relates point to cartographic point symbol in markerset geoscamp2.mrk

Attribute:

Attribute_Label: STRIKE

Attribute_Definition: Azimuthal strike of planar feature

Attribute:

Attribute_Label: DIP

Attribute_Definition: Dip of planar feature

Detailed_Description:

Entity_Type:

Entity_Type_Label: sun_ano.aat 
Entity_Type_Definition: Annotation leaders

Attribute:

Attribute_Label: L-SYMB

Attribute_Definition: Coded integer value (1) that relates arcs to cartographic line symbol in lineset geoscamp2.lin

Distribution_Information:

Distributor:

Contact_Information:

Contact_Organization_Primary:

Contact_Organization: U.S. Geological Survey Information Services

Contact_Address:

Address_Type: mailing address

Address: Box 25286 Denver Federal Center

City: Denver

State_or_Province: Colorado

Postal_Code: 80225

Country: USA

Contact_Voice_Telephone: (303)202-4700

Contact_Facsimile_Telephone: (303)202-4693

Distribution_Liability:

The U.S. Geological Survey (USGS) provides these geographic data "as is." The USGS makes no guarantee or warranty concerning the accuracy of information contained in the geographic data. The USGS further makes no warranties, either expressed or implied as to any other matter whatsoever, including, without limitation, the condition of the product, or its fitness for use lies entirely with the user. Although these data have been processed successfully on computers at the USGS, no warranty, expressed or implied, is made by the USGS regarding the use of these data on any other system, nor does the fact of distribution constitute or imply any such warranty.

In no event shall the USGS have any liability whatsoever for payment of any consequential, incidental, indirect, special, or tort damages of any kind, including, but not limited to, any loss of profits arising out of use of or reliance on the geographic data or arising out of the delivery, installation, operation, or support by USGS.

This digital geologic map database of the Sunnymead 7.5' quadrangle, 1:24,000 map-scale, and any derivative maps thereof, is not meant to be used or displayed at any scale larger than 1:24,000 (e.g., $1: 12,000)$.

Metadata_Reference_Information:

Metadata_Date: 20011003

Metadata_Review_Date: 20011116

Metadata_Contact:

Contact_Information:

Contact_Organization_Primary:

Contact_Organization: U.S. Geological Survey

Contact_Person: Rachel M.H. Alvarez

Contact_Position: Geologist

Contact_Address:

Address_Type: mailing address

Address: U.S. Geological Survey

Address: Department of Earth Sciences

Address: University of California, Riverside

City: Riverside

State_or_Province: California

Postal_Code: 92521

Country: USA

Contact_Voice_Telephone: (909) 276-6397

Contact_Facsimile_Telephone: (909) 276-6295

Contact_Electronic_Mail_Address: rhauser@usgs.gov 
Metadata_Standard_Name: FGDC Content Standards for Digital Geospatial Metadata

Metadata_Standard_Version: Version of June 8, 1994

Metadata_Access_Constraints: none

Metadata_Use_Constraints: none 